\title{
Eternal spirituality: an outstanding aspect of Iranian islamic traditional medicine
}

\begin{abstract}
Today, spirituality is considered as an impartible, determinant section of medicine without which the health is not achieved. Although it is paid attention in research-based literature of modern current medicine, actually there is no considerable favor toward it among clinical practitioners. In contrast to modern medicine according which spirituality is confined to "what gives meaning to life and provides pleasure", Iranian-Islamic traditional medicine (IITM) introduces an eternal comprehensive pattern of spirituality involving both therapist and patient and their interaction with each other and with Lord too. According to Islamic doctrine, spirituality is attributed to relation between the human and Lord, and human spirit has several dignities among which "soul of faith" is the highest one among usual faithful people. A therapeutic intervention has majority efficacy when therapist is in a high dignity of spiritual state. Physician can also promote the moral state of patient by an efficient spiritual interacting. Moreover, it is considered a substantial therapeutic efficacy for a compassionate relation between therapist and patient based on religious, spiritual beliefs. Spiritual state of a patient has also a significant effect on his/her treatment, recovery, and well-being in favor of which have been done a main body of medical research. Apparently, we can reach to more favorite medical outcomes by observing the IITM recommendations toward spirituality.
\end{abstract}

Keywords: spirituality, traditional medicine, palliative health care
Volume 6 Issue 4 - 2017

\author{
Mehrdad Zeinalian, Mehdi Eshaghi, \\ Homayoun Naji, Sayed Mohammad, Masoud \\ Marandi , Sedigheh Asgary \\ Department of Molecular Medicine, Entekhab Cancer Control \\ Center (Isfahan), Iran
}

Correspondence: Sedigheh Asgary, Cardiovascular Research Center, Cardiovascular Institute, Isfahan University of medical Sciences, Iran, Email sasgary@yahoo.com

Received: October 31, 2016 | Published: April 21, 2017

\section{Introduction}

Nowadays, the role of spirituality in human health has been determined. So there are a growing body of literature to highlight the significance of spiritual beliefs among patients in preparing the best life quality and efficient medical care. ${ }^{1-4}$ According to some studies, there is an embrace of religion and spirituality in medical care, so without considering them, we cannot offer an efficient comprehensive medical care to the patients. ${ }^{5,6}$ Meanwhile, for a long time any discussions on spirituality and religion had been considered unsuitable in the medical education and practice. ${ }^{7}$ It is due to the materialistic philosophy of the modern medicine which could be traced to Rene Descartes, a seventeenth-century philosopher who believed the dominance of mechanical laws on the world processes without any meaning and purpose. $^{8}$

Today, with disclosure of the determinant role of spirituality in medicine, some courses on spirituality and medicine are offered in more than 70 medical schools in the United States. ${ }^{9}{ }^{10}$ In such courses, many aspects of spirituality are educated to students with concentration on the clinical incorporation of these subjects into pregnancy and childbirth, chronic pain, psychiatric illness, addiction and dependency disorders, disability, and care of the dying. ${ }^{7}$ Meanwhile, according to current modern medicine, physicians are trained to be objective scientists and it has been ignored the actual art of the medicine as a compassionate, caring profession. ${ }^{11}$

Iranian Islamic Traditional Medicine (IITM) as an ancient comprehensive medical school, has a holistic viewpoint toward the human health. ${ }^{12,13}$ IITM scholars believe that the essential facet of the human is related to his/her spiritual feature which has a determinant role to maintain and promote the human healt. ${ }^{14}$ Based on this advanced attitude, the fitness will not be achieved unless with a comprehensive attention to all spiritual and mental aspects of the patient along with the physical health. ${ }^{14-16}$ We try to describe a brief story about the spirituality in IITM in comparison to the modern medicine.

\section{Modern definition for spirituality}

Although there is no single, universal definition for spirituality, ${ }^{1,4,17}$ it has been defined as being wide-ranging of philosophical, religious, spiritual, and existential subjects arising in the clinical situation which were based on the theological, empirical, and clinical literature. ${ }^{18,19}$ The consensus definition is as follows: ${ }^{5,19}$ "Spirituality is the aspect of humanity that refers to the way individuals seek and express meaning and purpose and the way they experience their connectedness to the moment, to self, to others, to nature, and to the significant or sacred.

Traditionally, the meaning of spirituality has been attributed to a relation between the human and God. For example, according to Waaijman, spirituality is a process of re-formation which "aims to recover the original shape of man, the image of God. To accomplish this, the re-formation is oriented at a mold, which represents the original shape: in Judaism the Torah, in Christianity Christ, in Buddhism Buddha, in the Islam Muhammad. ${ }^{20}$ " The spirituality in recent literature is confined to "what gives meaning to life and provides pleasure", ${ }^{21,22}$ a definition which has been derived of Hedonism school according which the human pleasure is the most important intrinsic good and every person has right to do anything for achievement of his/ her favorite pleasure. ${ }^{23,24}$ Therefore, in modern current medicine, in contrast to IITM, spirituality differs with religiosity providing human pleasure even from secular ways. According to this view of point, spiritual care is limited to compassionate care, a medical service involving all aspects of patient such as emotional, spiritual, social, and physical. ${ }^{25}$ In such a view, spiritual care is defined on focusing on patient and his/her relation with therapist. It ignores the spiritual state of therapist and/or health care provider and their interaction with God, a determinant aspect of spiritual medicine which has been emphasized by IITM scholars. ${ }^{26,27}$

\section{The spirit dignities in Islamic doctrine}

According to IITM attitude, the human has been composed of 
integrating both immaterial and material aspects including spirit and body. This belief is derived from Islamic doctrine according which actual structure of the human is related to his/her spirit and spiritual aspect. ${ }^{8}$ There is difference between spirit and soul based on religious resources. ${ }^{28}$ For example Islamic word for soul is "Hayat" (Holy Ouran, 2:55, 3:2, 6:162, 77:26, 2:49, 2:164, ...) and Hebrew word for it is "nephesh" which means literally "life" (Gen 1:20-24, Joshua $2: 13$, Exodus $21: 23) .{ }^{29}$ It is commonly used for human, animal and all organisms. Moreover, "spirit" is referred to immaterial aspect of human and its equivalent word in the Hebrew is "ruach" (Num 16:22) while in Islamic resources two words of "Nafs" (Holy Ouran, 3:25, 3:30, 20:15, 5:32) and "Rouh" (Holy Ouran, 32:9, 15:29, 38:72) are apparently the best equivalent for this word. ${ }^{30,31}$ Islamic philosophers believe that most mental properties like awareness, individual identity, eternal life, psychological disorders, free will, and etc. are related to the spirit (NAFS) and its relation to the body. The original part of the human is spirit. According to Islamic doctrine, the human will be paid obeisance by the angels when the divine spirit is inspired in him. ${ }^{2}$ The human spirit is eternal due to being immaterial and dominant on body. The actual life is specified to the futurity and just other eternal world has the worth for living. ${ }^{32}$ According to Islamic resources, the spirit has some dignities which have been allocated to different aspects of the life; some related to material life and some related to eternal heavenly life. All persons have three spirit dignities, commonly: the spirit of body (Rouh-ol-badan), the spirit of force (Rouh-ol-ghovvah), and the spirit of lust (Rouh-o-shahvah). All corporeal needs like nutrition, sleep, and having sex are attributed to these common dignities which are also seen in the animal. The faithful people benefit from a forth spirit called the spirit of faith (Rouh-ol-Iman), while the prophets and virtuous people have a higher fifth dignity of the spirit called the innocence spirit (Rouh-ol-ghodos). We could attribute these five dignities of the spirit to the multiple degrees of the spirit including vegetal, animal, and human aspects. ${ }^{6}$ Actually, the human has only a single spirit, and the mentioned dignities are considered in a longitudinal relation with this individual spirit which are sometimes mentioned as the "spirit forces" (Ghova-ye-Nafs).

All spirit forces have some specific needs that cannot complied simultaneously. For example when you are deeply studying, you may forget the hunger. Accordingly, the art of spirituality is rise of the human from low animal dignity to high sublime dignities. Therefore, the spiritual health must be preferred than other aspects of the health.

On the other hand, the body and spirit could affect on each other; so corporal disorders can afflict the spirit, and vice versa. These interactions are so popular in medical literature, so a main body of the psychological research has been allocated to. . $1,33,34^{-}$

\section{The therapist and spirituality}

IITM scholars believe that all health-related behaviors of the human influence on his/her spirit more than affecting the body. Given the more significant role of the spirit in general fitness than the physical body, the spirit health must be paid more attention than the body. Moreover, the therapist has a determinant role to prepare a proper spiritual condition for the patient. A therapist who does not have a good spiritual state could not be successful during the treatment process. ${ }^{14,35-41}$ Also, as we mentioned, the high dignity of the spirit, according to Islamic doctrine, is attributed to the sincere faith in God. Therefore, without a faithful belief to God and its eternal infinite power and knowledge, how can a therapist have a good spiritual state to treat efficiently the patient?

Accordingly, IITM describes a more advanced feature of the spirituality in medicine which is referred to the relation between the therapist and Lord. This advanced description leads to a comprehensive definition of the personalized medicine in which even for a specific patient and a definite therapist, the therapeutic outcome can be different in dissimilar spiritual situations.

In addition, therapists must be involved to promote their patients' moral behaviors. IITM scholars accent on importance the moral interaction between therapist and patient. Therapist must speak patiently with his/her patient about the disease-related facts, including all therapeutic and health related behaviors. It must cover the spiritual sides of illness, so a physician should not neglect the patient's spirit. In this case, most part of the treatment would be easily happened by attracting the patient's confidence. ${ }^{40,42}$ Studies have presented a significant portion of patients would like to hear their spiritual beliefs from their physicians. ${ }^{9,43-45}$

\section{The patient and spirituality}

Rather than therapist, spirituality affects also the patient in both processes of treatment and recovery by reinforcement of his/her positive motivation and the efficacy of therapeutic methods. This facet of spirituality focuses to promote spiritual state of the patient to more non-materialistic heavenly dignities. According to Islamic doctrine, the trust to God is sufficient for target achievement. ${ }^{46}$ Of course, this trust won't be perfect without the human efforts ${ }^{47}$ This confidence turns on the light of hope, brighter than the past, in the patient's heart. It can also lead to a higher quality of life in patients with serious illnesses.

Many studies have indicated the efficacy of integrating religious and spiritual elements into treatment process. ${ }^{43-45}$ For example in one study, Curlin and their colleagues opened a bright window into uncovering the efficacy of religion and spirituality on patients and showed that religion and spirituality had a potential positive effect on patients' fitness. ${ }^{19}$ Moreover, some studies demonstrated the reduced mortality among those patients attending frequently in worship services, compared to those with no attendance in worship services. ${ }^{48}$ According to some studies on metastatic cancer patients, it was revealed there is more satisfaction with life, happier state, and reduced pain in patients with well religious and spiritual beliefs in comparison with others with poor spiritual views. ${ }^{20}$

\section{Islamic spirituality and universal prescription}

According to Holy Quran and Islamic resources, all heavenly religions have common principles due to single origin. The Lord says in Holy Quran: "Say, "O People (of) the Book! Come to a word equitable between us and between you - that not we worship except Allah, and not we associate partners with Him - anything and not take some of us (to) others (as) lords besides Allah." Then if they turn away, then say, "Bear witness that we (are) Muslims. ${ }^{49}$

On the other hand, In Islamic view all humans have Devine nature and are constitutionally considered Muslims..$^{50}$ Therefore, spirituality in IITM is not assigned to just Muslims and it includes all humans, regardless of their beliefs.

\section{Summary}

Although there is no universal consensus on a single definition for spirituality, IITM has presented an advanced comprehensive feature of spirituality according which both therapist or health care provider and patient has a determinant role. Based on Islamic doctrine, the original part of human is the spirit, and IITM scholars believe some heavenly dignities for human spirit in relation with Great Lord. The stronger linkage with God leads to higher spiritual state, both for therapist and 
patient. This spirituality promotes the efficacy of therapeutic methods and also well-being among patients. The fact about which there are a main body of research in modern current medicine. Moreover, an advanced facet of spirituality is also discussed in IITM according which the heavenly relation between therapist and great Lord Influences on efficacy of treatment, so a single therapeutic method may have different efficacy in variable spiritual states. Given the existence of most comprehensive spirituality feature in IITM, apparently we can achieve to high level of spirituality health by paying attention to these advanced Islamic recommendations.

\section{Acknowledgments}

None.

\section{Conflicts of interest}

Author declares there are no conflicts of interest.

\section{Funding}

None.

\section{References}

1. Morrell S, Taylor R, Lyle D. A review of health effects of aircraft noise. Aust N Z J Public Health. 1997;21(2):221-236.

2. Thompson SJ. Review: extraaural health effects of chronic noise exposu re in humans. Schriftenreihe des Vereins fur Wasser. Boden- und Lufthygiene. 1993;88:91-117.

3. de Jong RG. Review: extraaural health effects of aircraft noise Schriftenreihe ver Wasser Boden Lufthyg. 1993;88:250-270.

4. McLean EK, Tarnopolsky A. Noise, discomfort and mental health A review of the socio-medical implications of disturbance by noise. Psychol med. 1997;7(1):19-62.

5. Pirrera S, De Valck E, Cluydts R. Nocturnal road traffic noise: A review on its assessment and consequences on sleep and health. Environ Int. 2010;36(5):492-498.

6. Zaharna M, Guilleminault C. Sleep, noise and health: review. Noise Health. 2010;12(47):64-69.

7. Wilcock A, Manderson C, Weller R, et al. Does aromatherapy massage benefit patients with cancer attending a specialist palliative care day centre? Palliat Med. 2004;18(4):287-290.

8. Tetreault LF, Perron S, Smargiassi A. Cardiovascular health, trafficrelated air pollution and noise: are associations mutually confounded? A systematic review. Int J Public Health. 2013;58(5):649-666.

9. Westcombe AM, Gambles MA, Wilkinson SM, et al. Learning the hard way! Setting up an RCT of aromatherapy massage for patients with advanced cancer. Palliat Med. 2003;17(4):300-307.

10. Fellowes D, Barnes K, Wilkinson S. Aromatherapy and massage for symptom relief in patients with cancer. Cochrane Database Syst Rev. 2004;4(2):CD002287.

11. Mahendra Prashanth KV, Venugopalachar S. The possible influence of noise frequency components on the health of exposed industrial workers--a review. Noise Health. 2011;13(50):16-25.

12. Parvinroo S, Zahediasl S, Sabetkasaei M, et al. The effects of selected hot and cold temperament herbs based on Iranian traditional medicine on some metabolic parameters in normal rats. Iran $J$ Pharm Res. 2014;13(Suppl):177-184

13. Parsa M, Aramesh K, Larijani B. A comparison between conflict of interest in Western and Islamic literatures in the realm of medicine. $J$ Med Ethics Hist Med. 2014;7:7.
14. Yim VW, Ng AK, Tsang HW, et al. A review on the effects of aromatherapy for patients with depressive symptoms. Journal of alternative and complementary medicine. 2009;15(2):87-95.

15. Alrawi SN, Fetters MD. Traditional arabic \& islamic medicine: a conceptual model for clinicians and researchers. Glob J Health Sci. 2012;4(3):164-169.

16. Khiewkhern S, Promthet S, Sukprasert A, et al. Effectiveness of aromatherapy with light thai massage for cellular immunity improvement in colorectal cancer patients receiving chemotherapy. Asian Pac J Cancer Prev. 2016;14(6):3903-3907.

17. Makopa Kenda I, Agoub M, Ahami AO. [Noise Effects on Menta Health: a review of literature]. Sante Ment Que. 2014;39(2):169-181.

18. Hohmann C, Grabenhenrich L, de Kluizenaar Y, et al. Health effects of chronic noise exposure in pregnancy and childhood: a systematic review initiated by ENRIECO. Int J Hyg Environ Health. 2013;216(3):217-229.

19. Stansfeld SA, Haines MM, Burr M, et al. A Review of Environmental Noise and Mental Health. Noise Health. 2000;2(8):1-8.

20. Schmidt JH, Klokker M. Health effects related to wind turbine noise exposure: a systematic review. PloS One. 2014;9(12):e114183.

21. Hunter JC. O monge e o executivo: uma história sobre a essência da liderança. Rio de Janeiro: sextant. 2004;3.

22. Rocha AC, Ciosak SI. Chronic disease in the elderly: spirituality and coping. Revista da Escola de Enfermagem da U S P. 2014; 48(2):87-93.

23. Crisp R. Hedonism reconsidered. Philosophy and Phenomenological Research. 2006;73(3):619-45.

24. Reiss S. Multifaceted nature of intrinsic motivation: The theory of 16 basic desires. Review of General Psychology. 2004;8(3):179.

25. Koenig HG. Religion, spirituality, and medicine: research findings and implications for clinical practice. South Med J. 2004;97(12):1194-200.

26. Jafari M, Alizadeh F, Zafarghandi N. Financial relation between physician and patient in medicine. Daneshvar. 2011;19(96):73-80.

27. Ghaffari F. A landscape of medical ethics and patient's rights in some traditional Islamic-Iranian medicine. History of Medicine. 2010 2(4):11-45.

28. Davarpanah M, Alavi SA, Rostaminasab A. Body, soul and spirit according to Imam Ghazzali and Acuinas. Religions and Mysticisem. 2011;44(1):63-93.

29. Beck JR. Self and soul: Exploring the boundary between psychotherapy and spiritual formation. Journal of Psychology and Theology. 2002;31(1):24-36.

30. Hajiali A, Ghasemnia S. The spirit and its protector, in Taregh chapter regarding on Molla Sadra and Tabatabayi attitude. Religious Human research. 2012;8(26):23-41.

31. Hosseini-Almousavi M, Avani GH. A review on spirit identity and quality of its belonging to body. Religious Human research. 2013;10(29):31-50.

32. van Kamp I, Davies H. Noise and health in vulnerable groups: a review. Noise Health. 2013;15(64):153-159.

33. Coenraads PJ, Goncalo M. Skin diseases with high public health impact Contact dermatitis. Eur J Dermatol. 2007;17(6):564-565.

34. Mallet I, Bomy H, Govaert N, et al. [Skin to skin contact in neonata care: knowledge and expectations of health professionals in 2 neonata intensive care units]. Arch Pediatr. 2007;14(7):881-886.

35. Hiatt JF . Spirituality, medicine, and healing. South Med J. 79(6):736743

36. Imanishi J, Kuriyama H, Shigemori I, et al. Anxiolytic effect of aromatherapy massage in patients with breast cancer. Evidence-based complementary and alternative medicine: $e C A M .2009 ; 6(1): 123-128$. 
37. Saniotis A. Islamic medicine and evolutionary medicine: a comparative analysis. J IMA. 2012;44(1).

38. Serfaty M, Wilkinson S, Freeman C, et al. The ToT study: helping with Touch or Talk (ToT): a pilot randomised controlled trial to examine the clinical effectiveness of aromatherapy massage versus cognitive behaviour therapy for emotional distress in patients in cancer/palliative care. Psychooncology. 2012;21(5):563-569.

39. Anandarajah G, Roseman JL. A qualitative study of physicians' views on compassionate patient care and spirituality: medicine as a spiritual practice? R I Med J. 2014;97(3):17-22.

40. Boehm K, Bussing A, Ostermann T. Aromatherapy as an adjuvant treatment in cancer care--a descriptive systematic review. Afr J Tradit Complement Altern Med. 2012;9(4):503-518.

41. Rezaeizadeh H, Alizadeh M, Naseri M, et al. The traditional Iranian medicine point of view on health and disease. Iranian journal of public health. 2009;38(Suppl 1):169-172.

42. Scheurich N. Spirituality, medicine, and the possibility of wisdom. Journal of general internal medicine. 2005;20(4):379-380.
43. Cawthorn A, Carter A. Aromatherapy and its application in cancer and palliative care. Complement Ther Nurs Midwifery. 2000;6(2):83-86.

44. Campbell L, Pollard A, Roeton C. The development of clinical practice guidelines for the use of aromatherapy in a cancer setting. Aust J Holist Nurs. 2001;8(1):14-22.

45. Dunwoody L, Smyth A, Davidson R. Cancer patients' experiences and evaluations of aromatherapy massage in palliative care. Int $J$ Palliat Nurs. 2002;8(10):497-504.

46. Tanglertsampan C, Patrakarn S, Vassansiri E. Contact urticaria from rubber gloves: an occupational skin disorder for health care workers. Journal of the Medical Association of Thailand. 1998;81(1):71-74.

47. Knackstedt TJ, Zug KA. T cell lymphomatoid contact dermatitis: a challenging case and review of the literature. Contact dermatitis. 2015;72(2):65-74.

48. Kite SM, Maher EJ, Anderson K, et al. Development of an aromatherapy service at a Cancer Centre. Palliative medicine. 1998;12(3):171-180.

49. Holy Quran. 3th chapter, versus: 64. Translator: Abdul Majid Daryabadi.

50. Holy Quran. 30th chapter, versus: 30 Translator: Abdul Majid Daryabadi. 